\title{
Audit Tenure and Audit
}

\section{Quality: the Renewal Sense of Comfort?}

\author{
Albert Agusto Buntara ${ }^{1}$ and Desi Adhariani ${ }^{2}$
}

\begin{abstract}
This study is aimed at providing empirical evidence on the association between audit tenure and audit quality to support the argument of the enactment of regulation on audit rotation in Indonesia. Using the theory of comfort perspective, this study focused on the person-to-person relationship; that is the relationship between partners of the public auditing firm and the client firm's CEO; as well as on the relations at the firm level. Panel regression is employed to study the association of audit tenure and audit quality. The results revealed the fact that the audit partner and CEO tenure measured by the years of the audit contract has a negative association with audit quality proxied by discretionary accruals. Furthermore, the tenure of the public auditing firm and the client's firm had a moderately significant positive impact on companies' audit quality. The results imply that the regulation of audit partner rotation is needed to renew the sense of comfort in terms of maintaining high audit quality.
\end{abstract}

JEL classification: M42

Keyword: audit quality, audit partner tenure, discretionary accrual, renewal comfort

\footnotetext{
${ }^{1}$ Department of Accounting, Faculty of Economics and Business, Universitas Indonesia

${ }^{2}$ Department of Accounting, Faculty of Economics and Business, Universitas Indonesia
} 


\section{Introduction}

Recently, there has been an issue of the expected decrease or diminishment of audit independence due to the high relationship between the auditor and the firm's top management. A recent case is Tesco, one of the largest retail stores in the world. This firm had an overstated profit of 263-million-pound sterling in September 2015, resulting from the misreporting of a booking payment from the suppliers. The scandal of Tesco resulted in the dismissal of some senior executives of the firm. Finally, this case was investigated by SFO (a kind of anti-fraud institution in England). This condition has triggered the disappointments among the investors in England and the United States of America. It is interesting to note that in this case, the condition was not disclosed by the auditor of Tesco, who was later known to have been the auditor of the firm for approximately 32 years. From the aforementioned case, the government and the investors may suspect that the case resulted from the close relationship between the top management of the firm and the auditor, which led to the diminishing independence of the auditor in carrying out the auditing service, this may potentially lead to legal problems for the firm in the future. It may be even worse than that the firm may collapse and become bankrupt.

In response to the aforementioned case, a great number of countries in the world have issued specific regulations concerning the audit partner rotation to prevent such fraud. The Sarbanes-Oxley Act is an example of such regulations. This act was developed to respond to the collapse of Enron. The content of Sarbanes-Oxley, in general, outlines the regulations concerning the independence of the auditor. This includes such matters as control of audit quality, audit partner rotation, and prohibition of conflict of interest. In Indonesia, the regulation on audit partner rotation was initially formulated in the Decree of the Ministry of Finance Number 423/KMK.06/2002 concerning the Public Accountant Service. In the Decree, it was stated that the provision of audit service for a financial report by an accounting firm to a client might be performed in maximally five consecutive years, while the tenure of an audit partner in a public auditing firm is maximally three consecutive fiscal years. Even further, the government has to improve the regulations concerning the services by public auditing firms in order to prevent unexpected incidences. The Decree of the Minister of Finance Number 423/KMK.06/2002 has been updated several times. The recent news on the relevant regulations concerning the audit partner rotation is the intention of the Otoritas Jasa Keuangan Indonesia (Indonesia's Financial Service Authority) to formulate a new regulation based on the results of studies and public opinion. In the draft of regulation, the government intended to amend the prevailing regulation (Government Regulation No. 20 of 2015 concerning the Practice of Public) into a revised version of regulation limiting the tenure of the Audit Partners and Public auditing firms to be maximally 5 years and 10 years, respectively.

Usually, the high risk and the attention of the public and investors have urged the academicians to undertake a further study. A number of studies have investigated the relationship between the partners of public auditing firms and clients' CEO and the relationship to audit quality. Such researchers as Ghosh and Moon (2002) and Myers et al., (2003) found that the longer tenure of the auditor would have an effect on the 
decrease of profit management in particular items. Another study was conducted by Carey and Simnett (2006). They found that long tenure of audit has a consistent relationship to audit quality. This study refers to the results of the study conducted by Ball et al. (2015), who investigated the factor of interpersonal relationship between Public auditing firm's Partner and client's CEO to audit quality using the samples of firm's financial reports in Australia during the last 9 years. Ball's study revealed that the audit quality would decrease when the interpersonal relationship between accounting public firm's partner and client' CEO was intensely established. In Indonesia, a similar study has been conducted by Novianti, Sutrisno, and Irianto (2009). Their similar results revealed that when the interpersonal relationship between partner and client's corporate CEO was intensely established, it would lead to lower audit quality.

Although audit partner rotation regulation has been enacted and a number of studies have been conducted, the effect of audit partner rotation on audit quality has been debatable. Proponents of audit rotation suggest that audit rotation may lead to improving audit independence. This proposition has been supported by some studies such as the one conducted by Hamilton et al. (2005), revealing that audit partner rotation may result in the decrease of discretionary accruals that further lead to better profit management in the financial report. On the other hand, the opponents of audit rotation suggest that mandatory rotation may lead to a decreased level of audit competency, because the longer tenure of the audit may lead to better knowledge of an auditor about the clients towards a better quality of audit output. Another study by St. Pierre and Anderson (1984) confirmed that audit mistake and law-breaking acts of auditor might occur at the initial year of audit contract.

Another research gap is the lack of an alternative perspective of auditing to explain the audit rotation other than the positive agency perspective. This study aims at providing empirical evidence of the relationship between audit quality and audit tenure to support the arguments of the enactment of audit rotation regulation in Indonesia. Using the theory of comfort as the sociological strand of auditing not much explored in previous studies (Pentland, 1993; Power, 1999; Humphrey and Owen, 2000; Carrington and Catasús, 2007), this research seeks to fill the research gap on the alternative theoretical basis of audit rotation.

The main research question that emanates from this study is: Do the relationships between audit partner and the CEO of the client company, as well as the relations at the firm level, impact the audit quality? This study focuses on person-to-person relationship, which is the relationship between a partner of public auditing firm and the firm's CEO. Although the focus is a person-to-person relationship, the researchers also include the effect of tenure between the audit firm and the client's firm, since they are inseparable entities in the audit contract. In this study, the researchers take samples of the whole non-financial public companies listed on the Indonesia Stock Exchange already audited by the public auditing firm. The observation years of this study were 2010-2014, which is in line with the maximum limit of the prevailing governmental regulation on audit rotation in Indonesia.

\section{Theoretical Review}




\subsection{Theory of Comfort}

The theory of comfort is an alternative perspective of auditing, to complement the mainstream definition of auditing as an objective evaluation regarding assertions about economic actions, views auditing as a ritualistic process of producing comfort at the micro-level (Pentland, 1993). The activity of producing comfort enables the macrosystemic function of trust in numbers; in order to transform the financial statements from an inherently untrustworthy state in the lack of trust society into a form that the auditors and the public can find comfortable.

The concept of comfort is developed in nursing practice (Kolcaba and Kolcaba, 1991) to provide comfort to patients and their families through comfort measures as the interventions. The idea of relief from a discomfort state can also be applied in other disciplines, including in auditing (Carrington and Catasús, 2007). Kolcaba (2003) defined three technical senses of comfort relevant in nursing theory, from which the application in auditing context was further delineated by Carrington and Catasús (2007) as follows.

Table 1. Comfort state in nursing practices and respective auditing counterparts

\section{Comfort state in nursing practices Application in the auditing context}

(Kolcaba, 2003) $\quad$ (Carrington and Catasús, 2007)

The state sense is all possible outcomes of Comfort as the state relates to the situation when the comfort, which is determined by the conditions that build comfort. The state sense suggests that there are both comforts and discomforts at any moment.

relevant actors have been convinced and when it is time to close the books and give an audit opinion. Comfort as a state highlights a case where sufficient efforts have been invested in being able to give an opinion. Most often, the state of comfort determines at what state the audit surpasses the line to produce a clean sheet. Consequently, this view acknowledges that auditing is not about reaching a $100 \%$ assurance of the audited number and that the auditing rationale is to accept some discomforts. Comfort as a state is about finding the situation where the auditors are comfortable enough with the numbers to give a (favorable) opinion.

The relief sense is the acts that relieve discomforts. By relieving discomforts, a non-acceptable state of comfort can be turned into an acceptable state. Relief refers therefore to the acts that aim at eliminating discomforts.

The renewal sense is a revitalization of how comfort is perceived. Renewal, consequently, is about new perceptions of acts that relieve from discomforts and new perceptions of the state of discomforts and comforts.
In auditing, the relief sense of comfort is understood as the acts that move the auditor from a state of uncomfort to a state of comfort. That is, comfort as relief frames what the auditors do to relieve from discomforts and become comfortable. The relief sense, consequently, highlights the practice of audits and, more specifically, about teasing out the acts that are obligatory to perform.

Translated into the audit setting, the renewal of the state of comfort relates to new definitions of what is an acceptable audit: what the auditor is comfortable with in one place or during one period might change. Renewing the audit has been at the forefront of the agenda for quite some time now. The debate on whether auditor rotations enhance audit quality may serve as an example of the renewal sense of comfort (Myers et al., 2003). The simple tenure-audit quality relation suggests that an auditor is less likely to sign a qualified audit report if s/he has been the company's auditor for a longer time. The argument rests on the idea that there is no renewal of the level of where the auditor reaches a state of comfort. Comfort as renewal concerns the change in the definition that determines the state of comfort.

Source: modified from Carrington and Catasús (2007) 
Based on Table 1, it can be seen that this study is more closely related to the renewal sense of comfort, which is reflected in the debate on auditor rotation and audit tenureaudit quality association.

\subsection{Hypothesis Development}

This study measures the association between a partner of a public auditing firm and a client's corporate CEO. Previous studies have formulated the various contrasting impacts of the relationship of partner. The first proposition suggests that longer interpersonal relationship between the partner and CEO will have a negative effect on audit quality. This is so because a longer audit contract may lead to a closer interpersonal relationship between the auditor partner and the client's CEO. The interpersonal relationship may have a large impact on the independence of the auditor, which may lead to lower audit quality (Mautz and Sharaft, 1961; Kaplan, 2004; Gavious, 2007; Chi et al., 2005 in Fitriany, 2011). The second proposition suggests that interpersonal relationship between partner and CEO may lead to a positive effect on audit quality since there are many audit mistakes, errors, and law-breaking by the auditor at the initial year of audit contract. It may also result from the fact that a new audit contract has a larger budget, which may have an effect on the audit fee as a whole. Another factor is that auditor has not understood the client comprehensively at the initial year of audit contract, leading to higher audit risk at the initial year of the audit contract. (Francis and Simon, 1987; Balvers et al., 1988; Beatty, 1989; Craswell et al., 1995).

The two propositions are directly proven in previous studies. Results of the study conducted by Ball et al. (2015) in companies in Australia for 9-year financial report reveal that lower audit quality will result when the interpersonal relationship between partner and client's corporate CEO is intensely established. Ghosh and moon (2002) and Myers et al., (2003) found that longer tenure of an auditor may affect profit management decreasing at particular items. The study conducted by Carey and Simnett (2006) found that longer tenure of the audit may have a consistent relationship to audit quality. A similar study has been carried out by Novianti, Sutrisno, and Irianto (2009). They found that lower audit quality might result when the interpersonal relationship between partner and client's corporate CEO is established. However, they disagree with the implementation of mandatory audit partner rotation. They argued that the replacement of a partner in the same public auditing firm would not have much effect on audit quality as a whole.

Based on the studies above, although they have conflicting results, this study predicts that there is a negative relationship between a longer interpersonal relationship between audit partner and client's CEO Client and audit quality. This study hypothesizes that the relationship may be in the form of a negative relationship since the auditor is a professional and competent auditor. Consequently, in the relationship between partner and auditor, the factor of auditor's learning experience on the client does no longer exist. This is also consistent with the comfort theory lens: the long interpersonal relationship brings about "comfort" in the numbers produced by audit clients hence creating over the trust that hamper the audit quality.

This study also measures the relationship between a public auditing firm and the client's firm based on contract tenure. It is suggested that the relationship between a public auditing firm and the client's firm should have had a positive impact on audit quality. 
The result from a public auditing firm should have been more independent than the result from a partner since the teamwork of public auditing firm is divided into several teams and, since the teamwork of audit for each period of contract is rotated, although the partner audit is still the same. Therefore, the independence problem is lower. Based on previous studies, the relationship of public auditing firm which is counted on the basis of tenure of public auditing firm also results in either positive or negative result.

The first proposition suggests that tenure of public auditing firm has a positive effect on audit quality because the longer the tenure of the audit, the better understanding the auditor has about the client, which may lead to better audit quality as a whole. The finding is confirmed by De Crabtree et al. (2006) who suggest that longer tenure of the audit may lead to the development of business knowledge to be the base for the designing of the effective and high-quality audit program.

The second proposition suggests that tenure of public auditing firm has a negative effect on audit quality since the longer the tenure of the audit, the closer relationship between auditor partner and CEO will be, which leads to lower audit independence and lower audit quality. One of the proponents of this proposition is study is Brooks et al. (2012) who studied companies in the United States of America. The study found a negative relationship between the tenure of public auditing firm and audit quality. Brooks suggests that at the initial phase of the contract until the period of 12 years, there will be an improvement of audit quality resulting from the improvement of auditor's understanding of the client's firm. After passing the period, audit quality will decrease in line with the improvement of the relationship between public auditing firm and client. Wahyuni (2014) also studied the effect of audit tenure, audit specialization, and client's importance on audit quality. She suggests that tenure public auditing firm has no significant relationship to audit quality in the period after the regulation limits audit tenure in Indonesia.

Based on the explanation above, this study predicts that there is a relationship between a public auditing firm and the client's firm and audit quality. In spite of the different results of the study, this study hypothesizes that the relationship may be positive due to the aforementioned paradigm. The hypothesis is as follows:

\section{H1: the interpersonal relationship between the audit partner and the client's corporate $\mathrm{CEO}$ has a negative effect on audit quality}

\section{H2: the relationship between public auditing firm and the client's firm has a positive effect on audit quality}

\section{Research Method}

Considering that this study uses panel data, in the testing of the hypothesis of the study, we employ multiple regression with the interaction variable. This study employs the model employed in previous studies (Ball et al., 2015), to test the effect of the interpersonal relationship between auditor partner and client's corporate CEO. The basic model is presented in the following:

$$
\begin{gathered}
A Q=\alpha_{0}+\alpha_{1} \text { PartnerCEO }_{i t}+\alpha_{2} \text { AuditFirm }_{i t}+\alpha_{3} \text { MarketCap }_{i t}+\alpha_{3} \text { Leverage }_{i t} \\
+\alpha_{3} \text { ReturnOnAsset }_{i t}+\alpha_{3} \text { Age }_{i t}+\alpha_{3} \text { Loss }_{i t}+\alpha_{3} \text { BigFour }_{i t}+\varepsilon_{i t}
\end{gathered}
$$

where: 
$\mathrm{AQ}=$ Audit quality, or audit quality. This variable is measured by the level of earnings management in the audit report based on Kim et al. (2002);

PartnerCEO = tenure of interaction between a partner of public auditing firm and client's corporate CEO, based on the number of years a partner is in contract with the same CEO of a firm;

Audit firm = tenure of interaction between public auditing firm and client's firm, based on some years a public auditing firm is in contract with a firm. The calculated rotation is real rotation;

MarketCap $=$ firm size, based on the total asset of the firm at the end of the period.

Leverage $=$ measured by comparing the ratio of long-term debt of the company to the market price of a firm 's equity

Return on Asset = measured by comparing the net income to a total asset of the firm

Age $=$ age /duration of a firm listed in the Indonesian stock exchange.

Loss $=$ dummy variable to indicate if a company is suffering loss at the initial period of 2010.

BigFour $=$ dummy variable to indicate if a firm is in contract with a Big Four public auditing firm in the year 2010 .

\section{Operational Definition}

\section{Dependent variable: Audit Quality (AQ)}

In measuring the audit quality, this study employs the method of discretionary accruals. The lower the score of discretionary accruals with the value of zero, the more neutral the profit value reported in the financial report of the firm. The researchers employ the model introduced by Dechow et al. (1995) since Dechow et al.'s model (1995) is more accurate than the original model introduced by Jones (1991). Besides that, the Model of Dechow is designed to avoid the likelihood that Model of Jones is wrong in measuring discretionary accruals when the discretion is estimated through revenue. Model of Dechow is calculated with the following formula;

$$
\text { TACC }_{i, t} / T A_{i, t-1}=a_{1} \frac{1}{T A_{i, t-1}}+a_{2} \frac{\left(\Delta R E V_{i, t}-\Delta R E C_{i, t}\right)}{T A_{i, t-1}}+a_{3} \frac{P P E_{i, t}}{T A_{i, t-1}}+\varepsilon_{i, t}
$$

Description of the aforementioned model variable is as follow;

TACC.i,t = Total Accrual of firm i in year $\mathrm{t}$

TAit-1 = Total asset of firm $\mathrm{i}$ in year $\mathrm{t}-1$

$\triangle \mathrm{REVi}, \mathrm{t} \quad=$ income discrepancy of firm $\mathrm{i}$ between year $\mathrm{t}$ and year $\mathrm{t}-1$

$\triangle \mathrm{RECi}, \mathrm{t} \quad=$ discrepancy of receivables of firm $\mathrm{i}$ between year $\mathrm{t}$ and year $\mathrm{t}-1$

PPEi, $\quad=$ Gross fixed asset of firm $\mathrm{i}$ in year $\mathrm{t}$

In this model, total accruals (TACC) are calculated using the approach of cash flow, that is the discrepancy between net profit before extraordinary post and cash flow from operation. The non-discretionary accruals (NDAC) are fitted value of the above equation, while the discretionary accruals (DAC) are the residual value /error in this $\operatorname{model}\left(\varepsilon_{i, t}\right)$ 


\section{Independent variables: Relation between auditor and clients' corporate CEO, and the relationship between public auditing firm and client's firm}

In measuring the relationship between auditor and client, this study refers to previous studies. Calculation of the relationship between partner audit and CEO of the client is based on a number of years in which public auditing firm and client are respectively represented by the same partner and CEO.

Meanwhile, in measuring the relationship between public auditing firm and client's firm, this study refers to previous studies related to the tenure of the audit. Those studies are among others conducted by Ghosh and Moon (2005), Gunny et al. (2010) Lim and Tan (2010), and Myers, et al. (2003). The relation between public auditing firm and the client was measured by the firm-year of audit contract between a public auditing firm and client's firm. This point is adjusted to the Regulation of Finance Minister Number 423/KMK.06/2002 concerning the Audit Service, limiting the tenure of maximum 5 years.

\section{Control Variables}

Several control variables are used in this regression model due to the possible existence of other determinants resulting from the adjustment of the financial report. This study uses the same control variables as those used by Loyeung et al. (2014), as the basis from Ball (2015).

\section{Results and Analysis}

\section{Selection of Sample}

This study uses the sample of companies listed in the JSE listed in the index of Kompas 100 in the period of February 2016 and July 2016. A sample of this study consists of various Industries including the companies in the manufacture, cement, construction, cigarette, pharmacy, fishery, and textile. In 2016, there were 100 companies listed in the index of Kompas 100. Samples were selected by considering if the companies have met the criteria. A final number of sample of this study is 295 .

Table 2. Selection of sample

\begin{tabular}{|l|l|l|}
\hline Description & $\begin{array}{l}\text { Number } \\
\text { firms }\end{array}$ & $\begin{array}{l}\text { Number of } \\
\text { observation } \\
\text { (Firm Year) }\end{array}$ \\
\hline $\begin{array}{l}\text { Companies listed in the index of Kompas 100 in the } \\
\text { period of February 2016- July 2016 }\end{array}$ & 500 \\
\hline Financial / Investment Companies & $(15)$ & $(75)$ \\
\hline Companies with incomplete data in the year 2010-2014 & $(16)$ & $(80)$ \\
\hline $\begin{array}{l}\text { Companies reporting the financial report in currency } \\
\text { other than rupiah }\end{array}$ & $(10)$ & $(50)$ \\
\hline $\begin{array}{l}\text { Number of firm meeting the criteria of observation } \\
\mathbf{2 0 1 0 - 2 0 1 4}\end{array}$ & $\mathbf{5 9}$ & $\mathbf{2 9 5}$ \\
\hline
\end{tabular}

Source: Data processed

Based on the table of sample selection, it can be concluded that the study uses data balanced, meaning that the number of data is becoming the sample each year is fixed. 
The total number of companies meeting the criteria of observation from the year 2010 to 2014 is 59 , which is equal to 295 firm years.

\section{Descriptive Statistics}

This section describes the descriptive statistic of the model used in this study. The descriptive statistical analysis in this section will describe the value of each dependent variable, independent variable, and control variable in this study. The main objective of descriptive statistics is to extensively the investigated variables. In this section, a table containing the mean, standard deviation, lowest and highest values of all variables are presented. The results of descriptive statistics are presented in table 3 , with the following details:

Table 3. Descriptive Statistics of the Model

\begin{tabular}{|c|c|c|c|c|c|}
\hline Variable & Obs & Mean & $\begin{array}{l}\text { Standard } \\
\text { Deviation }\end{array}$ & Min. & Max. \\
\hline ABSDAC & & 0.088 & 0.218 & 0.001 & 3.514 \\
\hline Partner_CEO & & 1.498 & 0.684 & 1.000 & 3.000 \\
\hline FIRM & & 2.766 & 1.410 & 1 & 5 \\
\hline $\begin{array}{l}\text { Market Cap } \\
\text { (in Million } \\
\text { Rupiah) }\end{array}$ & & 15500000 & 19300000 & 235021 & 140895000 \\
\hline Leverage & & 0.436 & 0.523 & -1.393 & 3.550 \\
\hline Age & & 17.827 & 8.865 & -2.000 & 37.000 \\
\hline $\mathrm{ROA}$ & & 0.823 & 0.592 & 0.007 & 2.843 \\
\hline Loss & & 0.051 & 0.220 & 0 & 1 \\
\hline Big4 & & 0.542 & 0.499 & 0 & 1 \\
\hline \multicolumn{2}{|l|}{ Dummy variable } & \multicolumn{2}{|l|}{$\%$ value 1} & \multicolumn{2}{|c|}{$\%$ value 0} \\
\hline Loss & & \multicolumn{2}{|c|}{$5.80 \%$} & \multicolumn{2}{|c|}{$94.20 \%$} \\
\hline Big 4 & & \multicolumn{2}{|c|}{$53.62 \%$} & \multicolumn{2}{|c|}{$46.38 \%$} \\
\hline $\begin{array}{l}\text { Notes: } \\
\text { ABSDAC } \\
\text { Partner_CEO } \\
\text { FIRM } \\
\text { Market Cap } \\
\text { Leverage } \\
\text { Age } \\
\text { ROA } \\
\text { loss } \\
\text { Big } 4\end{array}$ & & \multicolumn{4}{|c|}{$\begin{array}{l}\text { Discretionary accruals (to measure Audit Quality) } \\
\text { Tenure of interpersonal partner-CEO } \\
\text { Tenure of public auditing firm - Client's firm } \\
\text { Size of firm } \\
\text { The ratio of long-term debt to total asset } \\
\text { Age of firm in } \\
\text { Return on Asset } \\
\text { Firm's financial condition of experiencing loss } \\
\text { Big } 4 \text { Public auditing firm }\end{array}$} \\
\hline
\end{tabular}

\section{Model Testing}

The regression testing for the model in this study has the Prob $>$ chi2 value of 0.000 , (significant at 99\%) meaning that it is lower than the alpha value of $0.05 \%$. This result indicates that at the interval confidence of $99 \%$, independent variables used in the model of this study that is ABSDAC and control variables of Partner_CEO, FIRM, Market cap, leverage, age, ROA, loss, and Big 4 significantly and collectively has an effect on the dependent variable of ABSDAC. 
Table 4. Regression Result of the Model

\begin{tabular}{|c|c|c|c|c|}
\hline \multicolumn{5}{|c|}{ Regression Results of the model } \\
\hline Hypothesis & \multicolumn{4}{|c|}{$\begin{array}{l}\text { Interpersonal relationship between audit partner and } \\
\text { clients' CEO has a negative effect on Audit quality. } \\
\text { - } \\
\text { Relation of public auditing firm and client's firm has a } \\
\text { positive effect on audit quality }\end{array}$} \\
\hline \multicolumn{5}{|l|}{ Model } \\
\hline Variable & $\begin{array}{l}\text { Expected } \\
\text { results }\end{array}$ & Coefficient & P-value & Significance \\
\hline Partner_CEO & + & .0414151 & 0.014 & $* *$ \\
\hline FIRM & - & -.0145443 & 0.070 & $*$ \\
\hline $\mathrm{AGE}$ & - & .0008422 & 0.312 & \\
\hline LEVERAGE & $+/-$ & -.0442162 & - & $*$ \\
\hline LOSS & + & -.3686209 & 0.001 & $* * *$ \\
\hline BIG4 & - & -.032164 & 0.146 & \\
\hline MARKET.CAP(LN) & - & .002277 & 0.412 & \\
\hline $\mathrm{ROA}$ & - & -.0036805 & 0.444 & \\
\hline Cons & & .0079589 & & \\
\hline $\mathrm{R}^{2}$ & \multicolumn{4}{|c|}{0.4138} \\
\hline Prob $>$ Chi2 & \multicolumn{4}{|c|}{0.0000} \\
\hline $\begin{array}{l}* * * \\
* * \\
*\end{array}$ & \multicolumn{4}{|c|}{$\begin{array}{l}\text { Level of significance } 1 \% \\
\text { Level of significance } 5 \% \\
\text { Level of significance } 10 \% \\
\end{array}$} \\
\hline Notes: & \multicolumn{4}{|c|}{$\begin{array}{l}\text { when a variable has a positive coefficient on ABSDAC, then the } \\
\text { variable will have a negative effect on Audit quality, and vice versa } \\
\text { (ABSDAC and Audit quality have an inverse relationship). }\end{array}$} \\
\hline
\end{tabular}

\section{Discussion}

The dependent variable used in the table is ABSDAC or discretionary accruals. Based on the previous description, discretionary accruals can be described further as the incentive for the management to manipulate profit. The descriptive statistic shows that the mean value of ABSDAC is.0876503, although the score is relatively low, the score shows the tendency that on average the firms in Indonesia perform profit management. The minimum value of ABSDAC is .0012459 , while the maximum value of ABSDAC is 3.5143, implying that the firms in Indonesia listed in the index of Kompas 100 perform profit management practices, either by mark up the profit or mark down the profit. The standard deviation of ABSDAC is 0.21765 , where with the standard deviation value higher than the mean implies various profit management practices.

The independent variables used in this study consist of two variables. They are PARTNER_CEO and FIRM. The first independent variable and the focus of this study is PARTNER_CEO, representing the tenure of partner and CEO. The descriptive statistic reveals that the mean of PARTNER CEO is 1.498305 , implying that on average the firms in Indonesia listed in the index of Kompas 100 has the contract of 1.49 year. The minimum contract is 1 year, and the maximum contract is 3 years. The standard deviation lower than the mean implies that the contracts are not varied, where most of the firms prefer to play in comfort zone, and thus have a contract of only 3 years, although the government regulation already requires that partner may have a contract for maximally 5 years. The second independent variable is FIRM, representing the tenure of public auditing firm and client's firm. Results of descriptive statistic reveal the mean value of FIRM of 2.766102, implying that in average the firms in Indonesia listed in the index of Kompas 100 practice contract with public auditing firm for 2.76 years, 
with the minimum contract of 1 year and maximum contract of 5 years. The standard deviation of FIRM is also low, implying that the contract of public auditing firm and client's firm is not varied, although the tenure between public auditing firm and client's firm is more various than the tenure of partner-CEO.

\section{Testing of Hypothesis 1}

The first hypothesis proposed in this study is the tenure of audit between of partner public auditing firm and clients' CEO. It shows a negative effect on audit quality. The audit quality uses the earnings management proxy, calculated using the modified Jones model. It is worth noting that previous results of profit management proxy have the inverse relationship to audit quality, where the high value of ABSDAC indicates low audit quality. Results of the testing of hypothesis 1 can be described as follow;

a.) Variable of Tenure of public auditing firm's partner and Clients' CEO (PARTNER.CEO)

The table reveals that the tenure of partner-CEO calculated on the basis of firm-year of the contract has a significant relationship at the level of $5 \%$ to audit quality using the proxy of discretionary accruals (ABSDAC). This is implied in p-value/2 of 0.014 , indicating that Partner-CEO has a significant effect on ABSDAC with the significance level of 5\%. The direction of the relationship between partner-CEO and ABSDAC is positive, as expected in this study. The significance and coefficient in a whole are in line with the hypothesis proposed in this study. Results of the study reveal that tenure of public accounting firm's partner and client's CEO will have a positive effect on firm's discretionary accruals, leading to negative impact on firm's audit quality in a whole. This is because the interpersonal relationship between the public auditing firm's partner and client's CEO tend to reach the interaction level that allows the auditor to lose the independence as the auditor leading to the lower audit quality. Results of this study are consistent to results of previous studies conducted by previous researchers such as Ball et al. (2015) who found that lower audit quality would result when the interpersonal relationship between partner and client's CEO is established. Results of this study are also consistent to the study conducted by Novianti, Sutrisno and Irianto (2009) who also found the same results, where lower audit quality may result when the tenure of partner and $\mathrm{CEO}$ is longer.

\section{Control variables}

Control variables Market cap, leverage, age, ROA, loss, and big4 are not found to have the association to ABSDAC except Leverage and loss. This is implied in $p$-value higher than 0.05 . The direction resulting from the control variable is the same as expected. It can be concluded that all control variables other than loss used in this study have no significant effect on audit quality since there are many other factors having an effect on audit quality as a whole. The variable of LOSS has a significant effect on audit quality, with a p-value of 0.002, (lower than 0.05). This may be due to the fact that the management (agent) would like to minimize the impact of the signal delivered by the financial report concerning the loss. It can be explained further by the signaling theory. Meanwhile, the variable of Leverage has a significant effect on audit quality having the $P$-Value of 0.098 (lower than 0.10). This finding is consistent with the expected result of the study, where Leverage can have a positive or negative effect on audit quality. The 
variable of Leverage has a positive effect on audit quality as suggested by DeFond and Jiambalvo (1994). They claim that firms with a high level of debt have incentives to artificially increase the profit to meet the debt covenant.

From the description of the regression of hypothesis 1, it can be concluded that hypothesis 1 in this study is accepted. The relationship between public auditing firm's partner and clients' CEO has a negative effect on audit quality.

\section{Testing of Hypothesis 2}

Hypothesis 2 in this study is tested using the same model as hypothesis 1 in this study. Because the two employ the same model, the test of the determinant coefficient and $\mathrm{F}$ test are not conducted in the testing of the second hypothesis since the use of the same model will lead to the same results. The following is the results of regression for the second hypothesis;

a) Variable of tenure of public auditing firm and client's firm (FIRM)

The table shows that the variable of tenure of the firm (FIRM) calculated on the basis of the firm-year of the contract has a significant relationship at the level of $10 \%$ to audit quality using the proxy of the discretionary accruals (ABSDAC) as implied in the pvalue/2 of 0.070 . It implies that tenure of public auditing firm and client's firm has a significant effect on ABSDAC with the significance level of 5\%. The direction resulting from the relationship between the variables of partner-CEO and ABSDAC is negative, as expected in this study. The significance and direction of the coefficient in a whole have been consistent with the hypothesis proposed in this study. Results of this study imply that tenure of public auditing firm and client's firm has a negative impact on the firm's discretionary accruals, which will lead to positive impact on firm's audit quality as a whole. This results from the fact that a public auditing firm is more resistant to independence than Partner. The resistance result from the division of public auditing firm team into some further smaller teams. Another contributing factor is the rotation of the audit work team of each period of the contract for the same audit partner. This may lead to a lower level of independence. Still, another factor is that the longer the tenure of the audit, the auditor will have a better understanding of the client, which in turn will improve the audit quality as a whole. As a whole, this study is in line with the proposition of the study conducted by De Crabtree et al. (2006) revealing that longer tenure of the audit will lead to better business knowledge to be a good basis for the designing of the effective and high-quality audit.

From the description of the regression of the model, it can be concluded that hypothesis 2 in this study is accepted. The relationship between public auditing firm and the client's firm has a positive effect on audit quality.

\section{Conclusions}

The objective of this study is to provide empirical evidence of the relationship between audit quality and tenure of the audit to justify the enactment of the audit rotation regulation in Indonesia. This study focuses more on the person-to-person relationship, which is the relationship between a partner of public auditing firm and the client's CEO. Although the focus is a person-to-person relationship, the researchers also 
include the effect of tenure between public auditing firm and client's firm, since they are inseparable entities in the audit contract. In this study, the researchers select samples of all non-financial public firms listed in Indonesia Stock Exchange that have been audited by the public auditing firm. Years of observation in this study range from 20102014 , following the maximum limit of government regulation concerning audit rotation.

In this study, the sample includes the firms listed in JSX listed in the index of Kompas 100 in the period of February 2016 and July 2016. The sample of this study comprises various types of industry, ranging from manufacture, cement, construction, cigarette, pharmacy, fishery, and textile. In 2016, there were 100 firms listed in the index of Kompas 100.

The dependent variable in this research is discretionary accruals. Based on the previous explanation, discretionary accruals can be described further as the incentive of the management to manipulate the profit. Results of descriptive statistics reveal that the mean value of discretionary accruals is relatively low. However, it reveals a tendency that on average the firms in Indonesia practice earnings management.

Independent variables used in this study consist of two variables. The first is the tenure of audit partner and client's CEO. Results of descriptive statistic show that the minimum contract is 1 year and the maximum contract is 3 years. Lower standard deviation than the mean implies that the variation of the contract is apparent, where most firms prefer to operate in comfort zone, by establishing the contract with a partner for only 3 years, although the government regulation has determined that partner may establish a contract of maximum 5 years. The second independent variable is the tenure of public auditing firm and client's firm. Results of descriptive statistic reveal that in average the firms in Indonesia listed in the index of Kompas 100 perform a contract with public auditing firm for 2.76 years, with a minimum contract of 1 year and maximum contract of 5 years. The standard deviation is also low, implying that contract of public auditing firm and client's firm is not various, although the tenure between public auditing firm and client's firm is more various than the tenure of partner-CEO.

Results of hypothesis testing show that tenure of partner-CEO has a moderately significant positive effect on discretionary accruals while the firm tenure has a negative effect as expected in this study. Significant result and coefficient direction as a whole are consistent with the hypothesis proposed in this study. This study implies that the regulation of audit partner rotation is needed to maintain a high audit quality. This is also consistent with the theory of comfort as the theoretical lens of this study: that audit rotation on the partner can result in a renewal of comfort due to new insights bring in the process of audit.

It is suggested that further studies perform further refinement on this issue. First, by using another proxy of audit quality to better represent audit quality, such as EarningsResponse Coefficient, while including the compliance with the prevailing regulations. Second, performing further test per industry considering the different characteristics of the industries. It is also important to incorporate other factors expected to have an effect on audit quality, such as corporate governance and internal factors at the firm level. And last but not least, performing studies using the data of the financial industry may generalize the results to other industry. 


\section{References}

Anderson-Gough, F, Grey, C \& Robson, K. (2001). Tests of time: organizational timereckoning and the making of accountants in two multi-national accounting firms, Accounting, Organizations and Society, 26, 2, 99-122 https://doi.org/10.1016/S0361-3682(00)00019-2

Arel, B., Brody, R., Pany, K. (2005). Audit firm rotation and audit quality. CPA J.75 (1), 36-39 https://doi.org/10.1016/S0882-6110(06)22001-7

Ball, F., Tyler, J., \& Wells, P. (2015). Is audit quality impacted by auditor relationships? Journal of Contemporary Accounting \& Economics 11, 166-181 https://doi.org/10.1016/j.jcae.2015.05.002

Balvers, R. J., McDonald, B., \& Miller, R. E. (1988) Underpricing of New Issues and the choice of auditor as signal of investment banker reputation. The accounting review, Vol. 6.4 605-622

Beatty R.P. (1989). Auditor reputation and the pricing of initial public offering, the accounting review 64(Oct), 693-709

Berne, Eric. (1964). Games people play. New York. Grove Press

Brooks, L. Z., Cheng, C. S., \& Reichelt, K. J. (2013). Audit firm tenure and audit quality: Evidence from U.S. Firms. Www.ssrn.com https://doi.org/10.2139/ssrn.2201350

Carcello, J.V., Roger, Hermanso, Neal, and McGrath. (1992). Audit quality attribute: the perception of audit partners, prepares, and financial statement users, auditing. Sarasota, spring. Vol 11

Carey, P., Simnett, R. (2006). Audit partner tenure and audit quality. Account. Rev. 81 (3), 653-676. https://doi.org/10.2308/accr.2006.81.3.653

Carrington, T., \& Catasús, B. (2007). Auditing stories about discomfort: Becoming comfortable with comfort theory. European Accounting Review, 16(1), 35-58. https://doi.org/10.1080/09638180701265846

Charles A. Bowsher. (2012). Auditor independence and audit firm rotation. https://pcaobus.org/Rulemaking/Docket037/ps_Bowsher.pdf. Accessed on 14 June 2016.

Chen C.Y., C,J. Lin, and Y.C. Lin. (2004). Audit partner tenure, audit firm tenure and discretionary accruals; does long auditor tenure impair earning quality? Working paper, Hong Kong University of Science and Technology

Chi, W., Huang, H., Liao, Y., \& Xie, H. (2005). Mandatory audit partner Rotation, audit quality, and market perception: evidence from Taiwan. Www.ssrn.com https://doi.org/10.2139/ssrn.717421

Craswell, A. T., Francis, J. R., \& Taylor, S. L. (1995). Auditor brand name reputations and industry specialization, Journal of Accounting and Economics (20) 297-322 https://doi.org/10.1016/0165-4101(95)00403-3

Dang, Li. (2004). Assessing Actual Audit Quality, Thesis (Ph.D.)--Drexel University

De Crabtree, A., D.M. Brandon. \& J.J. Maher. (2006). The impact of auditor tenure on initial Bond Rating. Advance on Accounting 22: 97-121 https://doi.org/10.1016/S0882-6110(06)22005-4

DeAngelo. (1981). Auditor size and audit quality, Journal of Accounting and Economics 3 (1) 167-175 https://doi.org/10.1016/0165-4101(81)90002-1

Dechow, P. M., Sloan, R. G., \& Sweeney, A. P. (1995). Detecting earnings management. The Accounting Review vol. 70 No. 2, 193-225

Deis Jr, D. R., \& Giroux, G. A. (1992). Determinants of audit quality in the public sector. The Accounting Review vol. 67, 3, 462-479

Duldt, B. W. And K. Giffin. (1985). Theoretical perspectives for nursing. Boston: Little, Brown, and Company. 
European Commission. Green paper of Audit Policy: Lessons from the Crisis

Fitriany (2011). Analisis komprehensif pengaruh kompetensi and independensi akuntan public terhadap audit quality, Disertasi. Fakultas Ekonomi Universitas Indonesia

Fitriany, Arie Wibowo (2009). Perlukah regulasi KAP di Indonesia, Laporan Project Grant Departemen Akuntansi FEUI 2008

Francis, J. R., \& Simon, D. T. (1987). A test of auditing pricing in the small-client segment of the U.S. Audit Market. The accounting review 145-57

Francis. (2004). What do we know about audit quality? The British Accounting Review 26, 345 - 368 https://doi.org/10.1016/j.bar.2004.09.003

Gavious. (2007). Alternative Perspectives to deal with auditor's agency problem, Critical perspectives on accounting 18, 451-467 https://doi.org/10.1016/i.cpa.2006.01.011

Geiger \& Raghunandan. (2002). Auditor tenure and audit reporting failure. Auditing: A journal of practice and theory 21 (1) 67-78 https://doi.org/10.2308/aud.2002.21.1.67

Ghosh \& Moon. (2005). Auditor tenure and perceptions of audit quality, the accounting review 80, 2, 585 - 612 https://doi.org/10.2308/accr.2005.80.2.585

Ghosh \& Moon. (2005). Does auditor tenure impair audit quality? The Accounting Review 80 (2): https://doi.org/10.2308/accr.2005.80.2.585

Gibb, Jack R. (2006). Defense Communication. Journal of Communication vol 11 issue 3. 141-148 https://doi.org/10.1111/j.1460-2466.1961.tb00344.x

Giri, F.E. (2010). Pengaruh tenur Kantor Akuntan Publik (KAP) and Reputasi KAP terhadap audit quality (Kasus rotasi wajib auditor di Indonesia). Simposium Nasional Akuntansi XIII Purwokerto

Gujarati Damodar N. (2003). Basic Econometrics 4th Edition. New York: McGraw Hill

Gunny, K., Krishnan, G. \& Zhang, T. (2010). Is audit quality associated with auditor tenure, industry expertise and fees? Evidence from PCAOB Opinions, Working paper on SSRN

Hamilton, J., Ruddock, C., Stokes, D. J., \& Taylor, S. L. (2005). Audit partner Rotation, Earnings Quality, and Earnings conservatism, www.ssrn.com https://doi.org/10.2139/ssrn.740846

Herbohn, K. (2004). Informal mentoring relationships and the career processes of public accountants. British Accounting Review, 36(4), 369-393. https://doi.org/10.1016/j.bar.2004.05.002

Homans, George. (1958). Social behavior as Exchange. American Journal of Sociology Vol. 63, No. 6, pp 597-606. https://doi.org/10.1086/222355

Humphrey, C. and Owen, D. (2000) Debating the 'power' of audit, International Journal of Auditing, (4), pp. 29-50. https://doi.org/10.1111/1099-1123.00302

International Federation of Accountants. (2009). December 15). ISA 200: Overall Objectives of the Independent Auditor and the Conduct of an Audit in Accordance with International Standards on Auditing,

Jackson, A. B., Moldrich, M., \& Roebuck, P. (2008). Mandatory audit firm rotation and audit quality. Managerial Auditing Journal https://doi.org/10.2139/ssrn.1000076

Johnson, V., Khurana, I., Reynolds, J. (2002). Audit-firm tenure and the quality of financial reports. Contemp. Account. Res. 19 (4), 637-660 https://doi.org/10.1506/LLTH-JXQV-8CEW-8MXD

Jones J. J. (1991). Earnings management during import relief investigations, Journal of accounting research, no. 04-13 https://doi.org/10.2307/2491047

Kaplan. (2004). The mother of all conflicts: Auditor and their clients, Illinois Public law and legal theory research series, no. 04-13 https://doi.org/10.2139/ssrn.556623 
Keputusan Menteri Keuangan (KMK) N0.359/KMK.06/2003. Tentang perubahan atas keputusan Menteri Keuangan Nomor 423/KMK.06/2002

Keputusan Menteri Keuangan Nomor 423/KMK.06/2002. Tentang jasa akuntan publik

Kim, J. B., Min, C. K., \& Yi, C. H. (2002). Auditor Designation, auditor independence, and earnings management: Evidence from Korea. Working paper, the Hong Kong Polytechnic University.

Kolcaba, K. Y., \& Kolcaba, R. J. (1991). An analysis of the concept of comfort. Journal of advanced nursing, 16(11), 1301-1310. https://doi.org/10.1111/j.1365-2648.1991.tb01558.x

Kolcaba, K. (2003). Comfort theory and practice: a vision for holistic health care and research. NY: Springer Publishing Company.

Lee Teck Heang \& Azham Md. Ali. (2008). Vol.4, No.12 (Serial No.43) Journal of Modern Accounting and Auditing

Leonora, S., Yuliawati, T., \& Sutanto, A. C. (2012). Hubungan masa perikatan audit dengan kualitas audit. Jurnal ilmiah Mahasiswa Universitas Surabaya Vol. 1 No. 1

Lewensohn. (2007). Auditor specialization, perceived audit quality, and audit fees in the local government audit market, Journal of Accounting and public policy 265, Elsevier https://doi.org/10.1016/j.jaccpubpol.2007.10.004

Lim, C., Tan, H., (2010). Does auditor tenure improve audit quality? Moderating effects of industry specialization and fee dependence. Contemp. Account.Res. 27 (3), 923-957. https://doi.org/10.1111/j.1911-3846.2010.01031.x

Loyeung, A., Matolcsy, Z., Weber, J., Wells, P. (2014). An analysis of the accounting errors that arise during the transition to IFRS. Working Paper, University of Technology, Sydney

Mann, Prem S. (1995). Introductory Statistics, 2nd ed. Wiley https://doi.org/10.2307/2532974

Mautz \& Sharaft, (1961). The philosophy of auditing, Sarasota. FL: American accounting association

Mulyadi. (2002). Auditing, Buku Dua, Edisi Ke Enam, Salemba Empat, Jakarta

Myers, J. N., Myers, L. A., \& Omer, T. C. (2003). Exploring the term of the auditorclient relationship and the quality of earnings: A case for mandatory auditor rotation?, The accounting review, 78(3), 779-799. https://doi.org/10.2308/accr.2003.78.3.779

Novianti, Sutrisno, and Irianto. (2009). Tenure Kantor Akuntan Publik, tenure partner audit, auditor spesialisasi industri, and audit quality. Simposium Nasional Akuntansi 15

Penman S. \& X. Zhang. (2002). Accounting Conservatism, the quality of Earnings, and Stock Returns. The Accounting Review 77.2 (April) 237-264. https://doi.org/10.2308/accr.2002.77.2.237

Pentland, B. T. (1993) Getting comfortable with the numbers: auditing and the microproduction of macro-order, Accounting, Organizations and Society, 18(7/8), pp. 605-620. https://doi.org/10.1016/0361-3682(93)90045-8

Peraturan Menteri Keuangan (PMK) No. 17/PMK.01/2008 Tentang Jasa Akuntan Publik

Peraturan Pemerintah (PP) No. 20, 2015 tentang Praktik Akuntan Publik (PP 20/2015)

Porter, B., Simon, J. \& Hatherly, D. (2005) Principles of external auditing. John Wiley \& Sons, Ltd.

Power, M. (2003) Auditing and the production of legitimacy, Accounting, Organizations and Society, 28(4), pp. 379-394. https://doi.org/10.1016/S0361$\underline{3682(01) 00047-2}$ 
Rakhmat, Jalaluddin. (1985). Psikologi Komunikasi. Penerbit Remaja Karya: Bandung.

Revsine, L., Collins, D. W., Johnson, W. B., \& Mittelstaedt, H. F. (2001). Financial Reporting and Analysis. Second edition. New Jersey. Prentice Hall

Reyna, Oscar Torres. (2007). Panel Data Analysis: Fixed and Random Effects using Stata v 4.2. Princeton University Data and Statistical Services.

Robbins, Stephen P., Timothy A. Judge. (2011). Organizational Behavior. Fifteenth Edition. New Jersey. Prentice Hall

Sarbanes-Oxley

Act.

(2002).

http://www.ey.com/Publication/vwLUAssets/The Sarbanes-

Oxley_Act_at_10_Enhancing_the_reliability_of_financial_reporting_and_audi t_quality/\$FILE/JJ0003.pdf

Scott, William R. (2009). Financial accounting theory. Fourth Edition. Prentice hall

St. Pierre, K. \& J. Anderson. (1984). An analysis of factors associated with Lawsuits against public accountants. The Accounting Review 59 (1), 242-263

Sundgren, S. (2009). Perceived audit quality, modified audit opinions and the likelihood of liquidating bankruptcy among financially weak firms. International Journal of Auditing, 13(3), 203-221. https://doi.org/10.1111/j.1099-1123.2009.00388.x

Svanberg, Jan. Peter Ohman. (2015). Auditors' identification with their clients: Effect on audit quality. The British Accounting Review 47. 395-408 https://doi.org/10.1016/j.bar.2014.08.003

Thibault, J. W., \& Kelley, H. H. (1952). The Social Psychology of Groups. New York: John Wiley \& Sons

Wahyuni, Sri, Febri Adi Suseno. (2014). Apakah tenure and reputasi Kantor Akuntan Publik dapat meningkatkan kualitas audit? Third economics \& business research festival

Watts, R., and Zimmerman, J. (1986). Positive Accounting Theory. New York, NY: Prentice Hall

Wibowo, A, \& Rossietta Hilda. (2009). Pengaruh masa penugasan audit terhadap kualitas audit dengan pendekatan earnings surprise benchmark pada perusahaan terbuka (Studi aturan rotasi audit di Indonesia). Makalah Seminar Nasional Akuntansi XII, Palembang

Wimot, William \& Jayce Hocker. (2010). Interpersonal Conflict 8th edition. McGraw Hill. 